\title{
A Circular Economy: Where Will It Take Us?
}

\author{
Jim Hart ${ }^{1}(\mathbb{D}) \cdot$ Francesco Pomponi $^{1,2}$
}

Received: 5 November 2020 / Accepted: 10 February 2021 / Published online: 9 March 2021

(C) The Author(s) 2021

\begin{abstract}
The avalanche of environmental challenges, from local to global and back, has prompted responses at all levels from personal to inter-governmental. The results of these responses have fallen in the range between useful and counterproductive, with many examples on each side, but the scale of the overall challenge continues to escalate. Moving towards a zero-carbon global economy through absolute reductions in fossil fuel usage is a sure way of mitigating climate change, and a range of environmental, social and economic benefits would follow. The case for a Circular Economy (CE), however, is less clear. Whilst some $\mathrm{CE}$ initiatives may lead to the decoupling of economic growth from resource extraction, this does not necessarily equate to reducing the rate of extraction. Thus, the contribution of $\mathrm{CE}$ to the achievement of environmental objectives globally cannot be taken for granted. In terms of social impact, the best that can be said is that CE might be neutral. Technologies that promote the 'sharing economy' for instance, often suggested as a crucial CE strategy, create opportunities for individual wealth accumulation, but are also a route to the gig economy and the casualisation of labour. CE is arguably a business imperative, but definitive evidence to support the idea of a circular economy that meets social and environmental goals needs development.
\end{abstract}

Keywords Circular business models · Sharing economy · Circular economy · Sustainability · Technology

\section{Introduction}

Only a particularly uncurious person could be unaware of the modern scourges of the natural environment, and their increasing incursions into our lived experiences. Familiar examples,

Jim Hart

j.hart@napier.ac.uk

1 Resource Efficient Built Environment Lab (REBEL), Edinburgh Napier University, 10 Colinton Road, Edinburgh EH10 5DT, UK

2 Cambridge Institute for Sustainability Leadership (CISL), University of Cambridge, 1 Trumpington Street, Cambridge CB2 1PZ, UK 
amongst many, include climate change [1], air pollution [2]; soil erosion [3] and deforestation [4]. The number of environmental challenges mounts up, with terms such as micro-plastics [5], and insectageddon [6] entering the lexicon in response to new information and data. The scale of individual challenges also continues to increase as emissions targets are missed and the increasing concentration of greenhouse gases (GHG) in the atmosphere continues to accelerate [7].

Whilst such challenges are sometimes tackled as discrete problems, their interrelationships indicate the need to tackle the root causes. In response to the need for fundamental change in the way we produce and consume, or the need to be seen to be responding to these challenges, the concept of a circular economy (CE) has recently gained traction. This offers an alternative to the more familiar linear 'makeuse-dispose' model of production and consumption.

This article offers a perspective on potential implications of CE implementation in terms of sustainability, considering possible benefits and costs to the environment, society and the economy, globally. Whilst not a systematic review of the literature, the authors use a selection of relevant and recent literature and examples to highlight areas where greater understanding is needed of how CE can be harnessed to humanity's collective benefit. It is also a plea for participants in the $\mathrm{CE}$ to evaluate their contribution to wider objectives, and not use involvement in CE as a 'get out of jail free' card.

The article begins with a discussion of circular economy in the context of policy and sustainability ('Policy Response' section) before looking at the role technology might have in finding a way forward for $\mathrm{CE}$ and discusses the absence of social benefit in some visions ('Technology to the Rescue?' section). This leads on to a discussion of steering CE away from an 'economy first' (and everything else last) in the 'Circular Economy-Economy First?' section, and ending with a look into the future.

\section{Policy Response}

The possible responses to environmental challenges are as numerous and varied as the problems themselves. Positive responses can range from the individual micro-effort to global agreements to force change. Citizens are politely encouraged to 'do their bit' by turning thermostats down and eschewing single-use plastic shopping bags, but such bottom-up efforts are unlikely to yield change at the scale required when 'the system' still depends on a paradigm of continuous growth which relies on selling more stuff to an ever growing number of citizens [8]. At the other end of the scale, governments can work together - as they have with the Montreal Protocol, and the Paris Agreement for instance, and set and enforce global caps on certain damaging activities with global effect.

In between these two extremes, there exists a huge range of possible responses from communities, entrepreneurs, corporations, and governments. These can, for instance, involve the development of new technologies and products, the accelerated roll-out of well-proven (but perhaps expensive) technologies, sustainable business models, and any number of types of incentives and regulatory measures. Arguably, underpinning such measures with a coherent philosophy and framework can help to mobilise society and ensure widespread engagement. This is the role of the umbrella terms 'sustainability' and 'circular economy'. 


\section{Sustainability and Circular Economy}

Sustainability and CE mean different things to different people, and-indeed-may be regarded as 'contested concepts', as noted by Korhonen et al. [9] in connection with CE. However, most reasonable observers would recognise that both should offer the prospect of progress towards environmental goals, amongst other things. The concept of sustainability [10] generally requires that attention is spread across environment, society, and economy, and their inter-connections. This is a rebuke to hard-nosed capitalists who believe in profit and economic growth at all costs. Equally, it is a reality check for environmentalists who want to put nature first, and everything else behind. There is little wrong with the concept of sustainability, other than the significant issue of its failure to be sufficiently understood and embraced [11, 12]: the continuing pre-eminence of economic growth metrics in public discourse is evidence of this $[13,14]$.

The alternative (or, potentially, complementary) vision of a CE has been put forward, and endorsed by organisations and businesses around the world, especially in the European Union (EU) [15] and China [16]. The sheer number of available definitions of CE is frequently commented on [17], and it may be too late for a unifying definition to emerge, as the concept has emerged through cross-breeding of related schools of thought over recent decades (many highlighted by Borrello et al. [18]) and undergone mutations to adapt to selection pressures imposed by different stakeholders, understanding the issue from different perspectives (e.g. macro, meso and micro scales [19]). The best that can be hoped for is that definitions with a clear pro-environment agenda offer sufficient gravitational pull to counter those primarily biased towards economic growth. Definitions sometimes include abstract concepts that may absorb more light than they shed [20]: for instance 'an economy that is restorative and regenerative by design' [21], (how and what does an economy regenerate, and who will design it? Morseletto's review [22] finds potential meaning in 'restorative' in the context of ecological improvement, but less in 'regenerative'). Some present CE as an economic strategy with environmental benefits on the side; and others suggest it is primarily a restatement of the waste hierarchy (reduce, reuse, recycle), although some implementations of CE emphasise 'recycle' more than 'reduce', thereby subverting it to the cause of unsustainable business as usual. Make do and mend [23] was tried during the war, but since then the idea and practice of recycling and recovery are the only alternative strategies to gain real traction [24], and deep CE-thinking is needed to push beyond this [25, 26]. Haas et al. [27] make the point that the ultimate objective of a sustainable $\mathrm{CE}$ should be absolute global reductions in resource extraction, waste and emissions. The success or failure of 'the' CE can be thus determined; on the other hand, CE-focussed projects, products and policies have to be judged on the much less clear measure of whether they demonstrably contribute to the greater goal.

A CE is not just about how we make and dispose of objects: how we use them, how we share them, who owns them, and how they are maintained and paid for are all grist to the CE mill, covered by the term Circular Business Models (CBMs) [28]. Altogether, this is too much to communicate within a pithy definition, and newcomers to $\mathrm{CE}$ are invited to consider it in relation to things as they are-styled in CE literature as the 'linear economy' with its makeuse-dispose approach. A circular economy appears to offer something for everyone. If the linear economy leaves you in a state of despair because of its wasteful treatment of natural resources, then you may warm to $\mathrm{CE}$. On the other hand, a businessperson comfortable with the status quo will require a sense of opportunity to excite their interest: this is often implied by suggestions of lower costs and higher margins [28, 29]. And those with heightened senses will 
hear a bandwagon starting to roll and catch a whiff of opportunity from government support (innovation funding and soft loans, for instance), and investment and custom from other businesses also wanting to get on board. Strategic partners of the Ellen MacArthur Foundation (EMF) - a well-known advocate of CE - include global names in technology, fashion, automotive, electrical, financial services, food, and household products. Whilst there are indications of worthwhile initiatives, there is little sign that fundamental business models and resulting environmental impacts are changed.

\section{Cautionary Tales}

In many cases, interventions on environmental challenges have yielded good results: governmental and inter-governmental work has resulted in huge progress on issues such as the stratospheric ozone hole [30], acid rain [31], and vehicular lead emissions [32]. Although not inspired by $\mathrm{CE}$ per se, these cases are beacons, showing that it is possible to pick off environmental challenges individually, and hinting at the potential power of systemic change, through $\mathrm{CE}$, addressing problems collectively. However, in other cases, pro-environment interventions may have been counterproductive, in that purportedly green or circular policies have had substantial side effects [33]. One example from many is the promotion of wood as an ecologically sound choice of heating fuel: this has resulted in $7.5 \%$ of homes in the UK burning wood for heating [34], emitting air pollution in the form of NOx and particulate matter, even in urban areas where illegal levels of air pollution are frequently recorded [35]. Subsidies supporting the combustion of biomass are sometimes so poorly designed that the rewards for consumption of fuel have exceeded the cost, leading to excessive fuel consumption [36]. And the subsidies for renewable power in the UK have resulted in annual imports of $6 \mathrm{Mt}$ of wood pellets per year from outside of the EU (95\% of this from across the Atlantic), primarily for a single power station [37]. The carbon footprint associated with the processing and transport of this material is troubling enough, but to ignore the long wait for the carbon emitted at combustion to be re-sequestered by replacement forest is risky [38]. Turning to cropland, two-thirds of cropland required for the EU's non-food requirements is from regions outside of the EU, and monitoring of displacement effects is needed [39]. Perhaps, as some suggest, the bioeconomy (compliant with many visions of $\mathrm{CE}$ ) is the inevitable contemporary synergy between capitalism and biotechnology [40].

A case which resonates with the general population is single-use plastics leading to the pollution of our oceans and rivers with single-use plastics [41]. Following China's ban on importation of plastic waste, parts of the waste industry elsewhere have found other outlets, with countries in South-East Asia experiencing increases in imports of hundreds of percent [42], vastly outstripping their capacity to manage the material in an environmentally responsible manner [43]. Bans and pricing mechanisms targeting plastic carrier bag consumption have been introduced around the world. In a sense, this looks like strong circularity [20], as it problematises the inflow of materials (whereas weak circularity focuses on outflows), but the collective impact is difficult to assess. Successes in some cases are counterbalanced by rebounds and negative side-effects in others [44]. These include increased demand for plastic garbage bags, a switch to more resourceintensive bags, and the substitution of banned single-use plastic bags with much heavier 'bags for life', which, despite their name are often discarded after one use because the small charge for such a bag is no disincentive when the single-use option is unavailable [45]. This might be corrected, for instance, by increasing the charges [46], including the differential between multi-use and single-use bags to reflect their different weights. 
In these examples, we see that narrow focus on one aspect of an environmental problem can result in unwanted side effects. A genuinely holistic approach is required for such problemsolving, and merely invoking $\mathrm{CE}$ is not sufficient. It is unlikely that everybody involved in such policy development is unaware of the potential problems, but may have been overwhelmed by pragmatism and politics, whereby policies under development are trimmed in various ways to make them more palatable [12, 47-50]. Enforcement is replaced with voluntary commitment; fees and charges are set at low levels so as not to cause alarm; and over-the-top subsidy might be seen as a simple method for meeting a particularly challenging objective.

Summing up, in order to deliver genuine environmental benefits whilst minimising side effects, CE policy needs to be reinforced with a robust framework of impact assessment, packaged with measurability and enforceability.

\section{Technology to the Rescue?}

It can be argued that new technologies offer an escape from the make-use-dispose treadmill that has increasingly caused environmental problems to mount up since the industrial revolution $[51,52]$. The role of digital technologies in reducing demand for newsprint is a case in point [53]. On the other hand, technology also contributes to problems that CE seeks to solve: the energy demands of big data [54], and the material resources required to support planned obsolescence [55] are examples. Technology itself is neutral: it is the application that matters.

So how might technology be used to insert delays and loops into linear systems, thereby slowing the extraction and disposal of primary resources?

New materials and industrial processes offer one route to more circular products. In the popular imagination, 3D Printing is almost the epitome of modern manufacturing, being high-tech, accessible, and capable of manufacturing small runs of bespoke designs with minimal set-up. Whilst 3D Printing enables the manufacture of a wide range of products - from plastic gizmos to bridges and buildings - potentially cutting out waste from the manufacturing process, there is no guarantee that this will increase circularity overall [56].

An ever-increasing number of products are now available made from recyclate [57], and from industrial and agricultural waste streams, which is to be welcomed. However, such advances can entrench recycling and therefore business as usual: clothing lines that rely on a limitless stream of PET (polyethylene terephthalate) bottles are potentially an example [58], whilst also likely adding to the burden of marine microplastics [5]. But some agricultural and food industry wastes are an inevitable part of the food system essential to human civilisation, and if they can be harnessed to make the products we as a society actually need, then this is good news. But this only works if the waste infrastructure is developed in parallel with product development [59-61]. For instance, the benefits of compostable biopolymers, whereby nutrients return to the soil from whence they came, are only realisable if the materials are actually sent for composting. This requires either that all plastics are compostable, or that technology is up to the task of identifying and separating compostable polymers from the rest. The alternative is that compostable materials contaminate the plastics recycling stream, and are either incinerated or landfilled along with it. Whatever the ultimate objective, before we achieve bioplastics waste treatment nirvana, a messy and potentially long transition takes place [62]. 


\section{Technology and Society—the Sharing Economy and Circular Business Models}

Technology is also a vital facilitator of the 'sharing economy' [63] (or 'collaborative consumption' [64] and 'peer to peer economy'), which is seen by some as a pillar of the circular economy [65]. But the circular embrace of the sharing is not necessarily reciprocated, withfor instance - a report on the sharing economy not referring to the circular economy [66]. Digital platforms enable the sharing economy (or, according to Belk [67], 'pseudo-sharing' when commercial activity is dressed up as community asset sharing) by allowing users to increase the utilisation of their assets, which can be a positive outcome for all parties directly involved (the lender, the borrower, and the platform). However, the environmental and social benefits outweighing the costs is by no means a given. Even in the case of a transaction as apparently benign as sharing an electric drill through a CE-inspired tool library, one should ask whether the counterfactual would have been the purchase of an additional drill by the frustrated borrower or whether it would instead have been avoidance of the purchase of the plasterboard or shelving that was behind the supposed need for a drill. Give someone a fish and you feed them for a day; lend them a bottom trawler and you wipe out life on the seafloor and impact biodiversity and fish stocks for years to come.

Anything that breaks the cycle of demand stimulation, de-unionisation, centralisation of wealth, purchase, regret and disposal that typifies the linear economy is likely to be a move in the right direction [68], and CBMs are proposed as a solution. But evidence that they can leverage progress on all of these issues is lacking, and even the premise that if we aim to own less stuff, then less stuff will be made is debatable. Uber increases the utilisation of vehicles for instance, but has resulted in more, not fewer, cars being on the road [69]. In future, when a fleet of driverless app-based taxis replaces a much larger fleet of privately owned vehicles, environmental efficiencies will result, as such vehicles will likely travel further in their lifetimes than typical private vehicles, thereby delivering greater service per unit of resource. But there may be more traffic overall on account of the low costs per mile. And more again, because the low cost of the system will undermine existing public transport, it might in effect become the new public transport. Other sharing opportunities are also likely to indirectly promote car usage: for instance apps that promote the sharing of parking spaces [66] which, in reducing costs to the driver, increase accessibility of city centres to the private car, undermining local authority traffic management and pollution control strategies and potentially depriving them of income (ideally for the public good) from their own facilities.

Peer-to-peer apps are also promoting CBMs in the rag trade, aiming to slow the turnover of fast fashion. The income gained by the dedicated followers of fashion renting out their spare clothes will, however, enable them to invest in more spare clothes, whilst adding to the procession of delivery vehicle traffic. The fundamental problem is that platforms designed to promote the sharing of excess stuff can lead to the purchase of excess stuff in order to 'share' it, thereby growing an income: there is a fluid boundary between altruistic motive of sharing and the profit motive [70]. Just as a housing is now viewed-by owners - as an investment as much as somewhere to live, clothing will become a 'gig' or 'side-hustle', rather than stuff to wear. Instagram micro-celebrities have been suggested as enablers to a wider adoption of clothes-renting [71], and it is easy to imagine how this triggers in turn another loop of a new post each day, with a new purchase to show. A more circular fashion choice would be along the lines of buying fewer items, of higher quality, sustainably sourced, and repairable. Undoubtedly, environmental impact would be reduced, but so would profit. 
Airbnb is a globally known case identifiable as a CBM as it enables the extraction of greater financial value from fixed resources (in this case, property), and in principle it could enable greater utilisation of spare rooms. The reality, though, is a distortion of the property market as investors build and buy in geographical hot-spots, hollowing out local communities and pouring more petrol onto the inferno of mass tourism [72, 73], whilst also undermining existing jobs in the hospitality industry $[74,75]$ : social and environmental sustainability are nowhere to be seen. Some of these risks are acknowledged by the Organisation for Economic Cooperation and Development [76]. Other business models in which the end-user is not the owner are also presented as CBMs, and described in such terms as 'servitisation' or 'product as service' models, but servitisation only contributes to environmental sustainability in quite narrow terms [77] and a possible consequence (arguably, indeed, the purpose) of servitisation is that the products become more accessible to users and are ultimately manufactured in greater quantity.

More behavioural science is needed to underpin claims of environmental sustainability, to avoid more examples of technologies intended to mitigate environmental impacts proving counterproductive to society [78]. Taking a broader perspective, CBMs may be environmentally meaningless in an otherwise linear economy.

\section{Asset Management}

If technology's involvement in the sharing economy does not necessarily benefit the environment, then where else can we look for examples of technology as an enabler of the circular economy? As so much of CE is about the utilisation and fate of 'stuff', then it is important that we know where our stuff is, how much of it there is, and what condition it is in. 'Smart-circular product-service systems' can capitalise on the increasing connectivity of all sorts of objects to enable remote monitoring and actuating of products, whilst offering analytical functions and growing product lifetime databases [79]. An EMF report [80] gives the example of prolonging vehicle lifetimes by using sensors to monitor usage and operating conditions, and alerting the owner to any abnormalities. In the construction of buildings, the same applies to all mechanical and electrical equipment: Building Information Modelling (BIM) can be used to house data on all aspects of the building [81], including materials passports, enabling the concept of 'Building As Material Banks' (BAMB) [82]. This allows rich data concerning the products and materials incorporated in a building to be passed to subsequent owners, facilitating repair and maintenance and — at the end of the building's life - reuse.

Collaboration and design tools in the construction value chain, such as BIM, are enablers of $\mathrm{CE}$ in construction [83], but a deeper commitment to digital approaches by the construction industry will be required to maximise the potential benefits of BAMB [84]. Materials passports will need to be kept alive as buildings are maintained and modified over a period of decades, supported by - for instance — blockchain. Integrating BIM data on materials within a building with geographic information systems will enable the production of regional data and forecasts on material flows, allowing strategic planning regarding reuse of materials as buildings reach the end of life. It is difficult to find optimal circularity strategies for the design and operation of buildings in general: materials are stored in the fabric of buildings for such long, and indeterminate periods, and buildings may have to go through unforeseeable sequences of changes of use, ownership, repair and adaptation [83]. However, approaches suggested here can support several of the strategies identified by Eberhardt et al. [85], such as reuse of components and materials, optimising built form, and design for disassembly and adaptability. 
Regardless of whether or not CE is the motivating force, it is clear that technologies under the $\mathrm{CE}$ 'umbrella' have the potential to further extend the effective and efficient operating period of a range of products, delivering the benefits associated with resource efficiency.

\section{Circular Economy-Economy First?}

Is the true purpose of $\mathrm{CE}$ economic growth rather than the amelioration of environmental pressures? One of the promises of CE is that it will result in the decoupling of economic growth from resource use but this is wishful thinking in the case of weak CE. The idea of decoupling itself is often poorly understood. In a study on low carbon cities in China [86, p. 15] the authors report the successful achievement of such decoupling because: 'the relationship between carbon emissions and economic development showed that GDP increased, and carbon emissions also increased; however, the economic growth rate was higher than the growth rate of carbon emissions'. This simply shows a reduced impact intensity per unit of GDP not that economic growth is free from additional environmental impact.

Without specific action to slow the input of virgin resources, waste reduction can reduce costs for producers, with consumers taking a share of the benefit, thereby initiating a rebound effect that results in increases in resource extraction, production and consumption, even though the quantity of waste itself may be reduced (Fig. 1). Zink and Geyer [87] have identified a set of circumstances where the environmental benefits of CE strategies are unlikely to be offset by rebound effects: these include circular products being straight substitutes for existing conventional ones (at a similar price, thereby not stimulating market growth), and such products should target satiable demand (therefore excluding electronics for the most part). Rebound effects, therefore, should be considered, but so as to maximise net overall benefit rather than to excuse inactivity.

The fact that $\mathrm{CE}$ is presented as a business opportunity within the current capitalist framework should arouse some suspicion. In most cases, CE is presented with the best of intentions, but it is susceptible to greenwashing and - ultimately - many products associated with $\mathrm{CE}$ are designed or redesigned to meet wants rather than needs, and the producer intends to make more of them, regardless of the business model. Whilst arguing for change, CE

Fig. 1 A metaphor for the circular economy in Vienna 2018: old materials generating revenue as they revolve. But energy/effort is needed to keep it moving. And even such a benign case is susceptible to rebound effects: will the revenue be reinvested in $\mathrm{CE}$ or in a new smartphone?

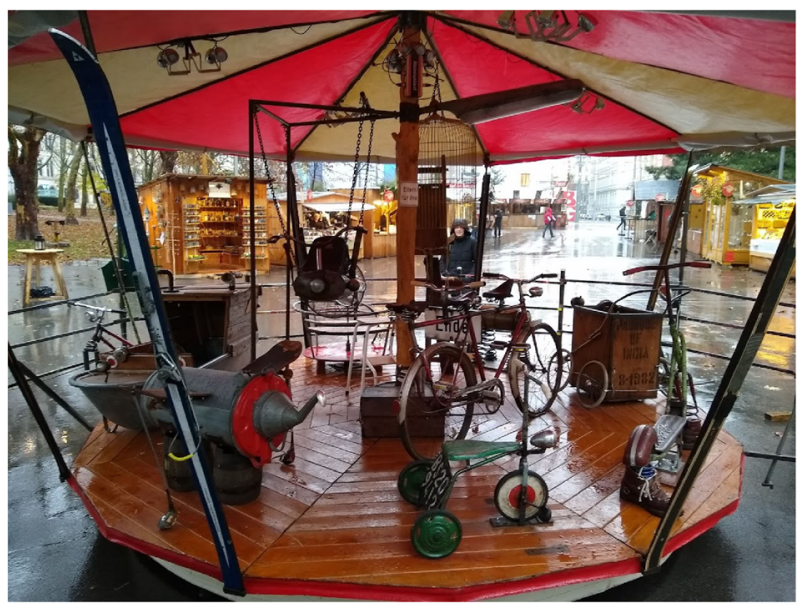


presents a vision that we can carry on living our lives as normal, with business adapting to serve every whim and an unrivalled and unverified faith in technological optimism. However, the science is clear: the challenges we are facing are enormous [68] and so we should be prepared to change rather than carry on living as normal.

As CE is typically articulated, there is no promise of simultaneous progress on the three foundations of sustainability - environment, society and economy. Each leg of the 3-legged stool is dependent on the other two to provide a secure connection between the surface we inhabit and the 'world turtle' on which it (mythologically) rests [88]. CE can narrow the discourse in relation to all three legs. For example, with respect to the environment, the focus on primary resources can promote a utilitarian approach to the environment, with a focus on natural capital rather than recognising biodiversity for its own sake [89]. This can be seen in how commercial forests are managed: species are chosen to maximise yield [90]. With respect to society, CBMs can provide benefit to those directly involved, but often without due consideration to people who have no stake, thereby incentivising the rentiers rather than the producers. Cutting out the middleperson can seem an attractive proposition - until we consider that we are almost all, to an extent, middlepeople.

\section{Where Next?}

By this point, it should be clear that for such a simple phrase, 'circular economy' disguises a wealth of complexity and challenges which should cause us to ask how it can be useful. Arguably, the discipline is at a crucial moment where amongst its hundreds of definitions we still need to find and agree on a model that determines CE's future fate either as the paradigm shift that the world needed in the twenty-first century or capitalism 2.0 redressed.

Circular things have more wholesome and organic connotations (the circle of life, the hydrological cycle, bicycle wheels) than linear ones (simplistic, one-dimensional) [91], so there is an immediate appeal to take the concept in uncritically. However, as a counterpoint, according to a popular search engine ${ }^{1}$, vicious circles are five times as common as the virtuous variety. It would be helpful to ask what conditions are needed to support a virtuous CE rather than a vicious one (for instance, a CE that meets the brief regarding economy and resources, but at the expense of human dignity, creativity and social equality).

A circular economy in which nothing is wasted can never be achieved [92], but humanity can at least move towards a circular ideal. On the other hand, we know that a modern zero-carbon economy is technically achievable by leaving fossil fuel in the ground and doing the best we can with renewable resources, for instance. Global lockdowns imposed to mitigate the spread of, and deaths caused by the COVID-19 pandemic, caused the largest drop in emissions ever recorded since records began [93]. The economy has certainly been hit hard as a result [94], emphasising how the world still resembles a see-saw with the economy at one end, and the environment at the other. If crucial tipping points have not yet been crossed, then going 'zero-carbon' will prevent catastrophic climate change. In fact, a zero-carbon economy — currently still a theoretical benchmark — is a basic pre-condition for a circular economy, as energy inputs will always be required to keep the circular economy turning. Therefore we should ask how CE might be a distraction from greater goals, and how it might be a key plank in the strategy for achieving such goals.

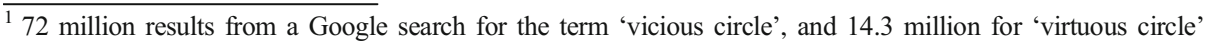
Nov 2020.
} 
At some point in the distant future, humanity might have extracted all the mineral resources it needs to last for generations beyond. With global fertility rate collapsing, and China's population supposed to halve by 2100 [95], will we be able to recognise when we have extracted enough to keep us going? Until that point, however, a CE continues to rely on extraction, as the requirement for new buildings and products - for instance to raise living standards in the global south to a reasonable level - continues to grow, always outstripping the availability of materials from end-oflife buildings and products. Thus, even a perfect scenario involves continuation of extraction for the foreseeable future. Perfection, in the form of zero waste, is itself a chimera [92]: assemblies wear out; materials degrade under environmental influences such as ultraviolet radiation and acidic rain; they erode, leaving micro-particles in water (from clothes washing), on surfaces (vehicle tyres), in the air (combustion); and even polymers once assumed to have been indigestible, such as PET, have been found to be susceptible to bacteriological degradation, potentially into its constituent monomers thereby offering a route towards a closed-loop recycling system [96].

Imagine a zero-carbon future: yes, sharing of resources and making the best use of what we have are likely to be part of it, but the main features of this future are likely to be either reverting to a 'simpler' way of life (appealing to a minority), or betting on technological progress to get us there. Various combinations of wind, solar, nuclear, energy storage and carbon capture would do the heavy lifting, enabled by data services, and maintain a recognisable standard of living. It is however important not to buy into unrealistic techno-optimism [97].

Now imagine a circular future. What does this look like? Perhaps a world in which objects are built to last indefinitely (or, better, exactly as long as needed, to avoid over-engineering), but made with minimal resource inputs: this would however be a world in which the needs of future generations are known to the present. Or a world without single-use plastics: but how do we replace or displace them? Single-use non-plastics, with their own challenges? A reverse logistics infrastructure for reusable packaging? Food products in their new genetically modified skins, enhanced for resilience?

A circular future is a less clear goal than the zero-carbon future, and therefore more difficult to model and plot a path towards it. Thus we should see circular economy as a journey, not a destination, which we embrace along with its contradictions. This should be within a sustainability context, and if weaker visions and definitions of CE do not become extinct, then it should be understood as belonging firmly to the economic pillar. In that case, $\mathrm{CE}$ will have to work alongside (and sometimes in opposition to) alternative visions for the environment and society, and their associated tools and metrics. In other words, we should jump on to the bandwagon, but should also upgrade the brakes and steering.

Abbreviations $B A M B$, building as material banks; $B I M$, building information modelling; $C B M$, circular business models; $C E$, circular economy; $E M F$, Ellen MacArthur Foundation; $E U$, European Union; $G H G$, greenhouse gases; $P E T$, polyethylene terephthalate

Data Availability Not applicable.

Code Availability Not applicable.

\section{Declarations}

Conflict of Interest The authors declare no competing interests. 
Open Access This article is licensed under a Creative Commons Attribution 4.0 International License, which permits use, sharing, adaptation, distribution and reproduction in any medium or format, as long as you give appropriate credit to the original author(s) and the source, provide a link to the Creative Commons licence, and indicate if changes were made. The images or other third party material in this article are included in the article's Creative Commons licence, unless indicated otherwise in a credit line to the material. If material is not included in the article's Creative Commons licence and your intended use is not permitted by statutory regulation or exceeds the permitted use, you will need to obtain permission directly from the copyright holder. To view a copy of this licence, visit http://creativecommons.org/licenses/by/4.0/.

\section{References}

1. L. Landrum, M.M. Holland, Extremes become routine in an emerging new Arctic, Nat Clim Change. (2020) 1-8. doi:https://doi.org/10.1038/s41558-020-0892-z.

2. Akimoto H (2003) Global Air Quality and Pollution. Science. 302:1716-1719. https://doi.org/10.1126/ science. 1092666

3. Guerra AJT, Fullen MA, do Carmo Oliveira JM, Bezerra JFR, Shokr MS (2017) Slope processes, mass movement and soil erosion: a review. Pedosphere 27:27-41. https://doi.org/10.1016/S1002-0160(17)60294-7

4. Andrée BPJ, Chamorro A, Spencer P, Koomen E, Dogo H (2019) Revisiting the relation between economic growth and the environment; a global assessment of deforestation, pollution and carbon emission. Renew Sust Energ Rev 114:109221. https://doi.org/10.1016/j.rser.2019.06.028

5. Auta HS, Emenike CU, Fauziah SH (2017) Distribution and importance of microplastics in the marine environment: a review of the sources, fate, effects, and potential solutions. Environ Int 102:165-176. https:// doi.org/10.1016/j.envint.2017.02.013

6. Thomas CD, Jones TH, Hartley SE (2019) "Insectageddon": a call for more robust data and rigorous analyses. Glob Chang Biol 25:1891-1892. https://doi.org/10.1111/gcb.14608

7. IEA, Energy Technology Perspectives 2020, International Energy Agency, 2020. https://www.iea.org/ reports/energy-technology-perspectives-2020 (accessed November 4, 2020)

8. Valenzuela F, Böhm S (2017) Against wasted politics: a critique of the circular economy. Ephemera: Theory \& Politics in Organization 17:23-30 http://www.ephemerajournal.org/contribution/against-wastedpolitics-critique-circular-economy (accessed October 29, 2020)

9. Korhonen J, Nuur C, Feldmann A, Birkie SE (2018) Circular economy as an essentially contested concept. J Clean Prod 175:544-552. https://doi.org/10.1016/j.jclepro.2017.12.111

10. Purvis B, Mao Y, Robinson D (2019) Three pillars of sustainability: in search of conceptual origins. Sustain Sci 14:681-695. https://doi.org/10.1007/s11625-018-0627-5

11. Brandt P, Ernst A, Gralla F, Luederitz C, Lang DJ, Newig J, Reinert F, Abson DJ, von Wehrden H (2013) A review of transdisciplinary research in sustainability science. Ecol Econ 92:1-15. https://doi.org/10.1016/j. ecolecon.2013.04.008

12. Howes M, Wortley L, Potts R, Dedekorkut-Howes A, Serrao-Neumann S, Davidson J, Smith T, Nunn P (2017) Environmental sustainability: a case of policy implementation failure? Sustainability. 9:165. https:// doi.org/10.3390/su9020165

13. Hoekstra R (2019) Replacing GDP by 2030: towards a common language for the well-being and sustainability community. Cambridge University Press, Cambridge

14. Jean-Paul F, Martine D, (2018) Beyond GDP measuring what counts for economic and social performance: measuring what counts for economic and social performance, OECD Publishing.

15. European Commission, (2020) A new circular economy action plan for a cleaner Europe, European Commission.

16. The Circular Economy Promotion Law of the People's Republic of China, (2008). https://ppp.worldbank.org/ public-private-partnership/sites/ppp.worldbank.org/files/documents/China_CircularEconomyLawEnglish. pdf. Accessed 7 Feb 2021

17. Kirchherr J, Reike D, Hekkert M (2017) Conceptualizing the circular economy: an analysis of 114 definitions, Resources. Conserv Recycl 127:221-232. https://doi.org/10.1016/j.resconrec.2017.09.005

18. Borrello M, Pascucci S, Cembalo L (2020) Three propositions to unify circular economy research: A review. Sustainability (Switzerland) 12:1-22. https://doi.org/10.3390/SU12104069

19. Kristensen HS, Mosgaard MA (2020) A review of micro level indicators for a circular economy-moving away from the three dimensions of sustainability? J Clean Prod 243:118531. https://doi.org/10.1016/j. jclepro.2019.118531 
20. Johansson N, Henriksson M (2020) Circular economy running in circles? A discourse analysis of shifts in ideas of circularity in Swedish environmental policy. Sustain Prod Consum 23:148-156. https://doi.org/10. 1016/j.spc.2020.05.005

21. Ellen MacArthur Foundation, McKinsey Center for Business and Environment, Growth Within (2015): A Circular Economy Vision for a Competitive Europe. https://www.ellenmacarthurfoundation.org/assets/downloads/ publications/EllenMacArthurFoundation_Growth-Within_July15.pdf (accessed November 4, 2020)

22. Morseletto P (2020) Restorative and regenerative: exploring the concepts in the circular economy. J Ind Ecol 24:763-773. https://doi.org/10.1111/jiec.12987

23. Ministry of Information, (2007) Make do and mend, Imperial War Museums

24. Morseletto P (2020) Targets for a circular economy, Resources. Conserv Recycl 153:104553. https://doi. org/10.1016/j.resconrec.2019.104553

25. Reike D, Vermeulen WJV, Witjes S (2018) The circular economy: new or refurbished as CE 3.0?exploring controversies in the conceptualization of the circular economy through a focus on history and resource value retention options. Resour Conserv Recycl 135:246-264. https://doi.org/10.1016/j.resconrec. 2017.08.027

26. Pomponi F, Moncaster A (2017) Circular economy for the built environment: A research framework. J Clean Prod 143:710-718

27. Haas W, Krausmann F, Wiedenhofer D, Lauk C, Mayer A (2020) Spaceship earth's odyssey to a circular economy-a century long perspective, Resources. Conserv Recycl 163:105076. https://doi.org/10.1016/j. resconrec.2020.105076

28. Lacy P, Rutqvist J (2016), Waste to wealth: the circular economy advantage, Springer

29. Hopkinson P, Zils M, Hawkins P, Roper S (2018) Managing a complex global circular economy business model: opportunities and challenges. Calif Manag Rev 60:71-94. https://doi.org/10.1177/ 0008125618764692

30. Kuttippurath J, Nair PJ (2017) The signs of Antarctic ozone hole recovery. Sci Rep 7:585. https://doi.org/10. 1038/s41598-017-00722-7

31. Fowler D, Smith R, Muller J, Cape JN, Sutton M, Erisman JW, Fagerli H, (2007) Long term trends in sulphur and nitrogen deposition in Europe and the cause of non-linearities BT-acid rain-deposition to recovery, in: P. Brimblecombe, H. Hara, D. Houle, M. Novak (Eds.), Springer Netherlands, Dordrecht. pp. 41-47. https://doi.org/10.1007/978-1-4020-5885-1_5

32. Kristensen LJ (2015) Quantification of atmospheric lead emissions from 70 years of leaded petrol consumption in Australia. Atmos Environ 111:195-201. https://doi.org/10.1016/j.atmosenv.2015.04.012

33. van der Ploeg F, Withagen C (2015) Global Warming and the Green paradox: a review of adverse effects of climate policies. Rev Environ Econ Policy 9:285-303. https://doi.org/10.1093/reep/rev008

34. DBEIS, (2016) Summary of the Domestic Wood Use Survey, https:/www.gov.uk/government/ publications/summary-results-of-the-domestic-wood-use-survey (accessed November 4, 2020)

35. Laybourn-Langton L, Quilter-Pinner H, Ho H, (2016) Lethal and illegal: solving London's air pollution crisis, Institute for Public Policy Research. https://www.ippr.org/publications/lethal-and-illegal-solvinglondons-air-pollution-crisis (accessed November 4, 2020)

36. McDowell I, (2018) RHI Enquiry: Cash-for-ash-the story so far. https://www.bbc.co.uk/news/uk-northernireland-45396818 (accessed November 4, 2020)

37. Drax group, Annual Report and Accounts, (2019). https://www.drax.com/wp-content/uploads/2020/03/ Drax_AR2019_Web.pdf (accessed November 4, 2020)

38. Sterman JD, Siegel L, Rooney-Varga JN, (2018) Does replacing coal with wood lower CO2emissions? Dynamic lifecycle analysis of wood bioenergy, Environmental Research Letters. 13. https://oi.org/10. 1088/1748-9326/aaa512

39. Bruckner M, Häyhä T, Giljum S, Maus V, Fischer G, Tramberend S, Börner J (2019) Quantifying the global cropland footprint of the European Union's non-food bioeconomy. Environ Res Lett 14:045011. https://doi. org/10.1088/1748-9326/ab07f5

40. Larsen LT (2007) Speaking truth to biopower. Distinktion: Journal of Social Theory 8:9-24. https://doi.org/ 10.1080/1600910X.2007.9672936

41. Dilkes-Hoffman L, Ashworth P, Laycock B, Pratt S, Lant P (2019) Public attitudes towards bioplasticsknowledge, perception and end-of-life management, Resources. Conserv Recycl 151:104479. https://doi. org/10.1016/j.resconrec.2019.104479

42. Wang C, Zhao L, Lim MK, Chen W-Q, Sutherland JW (2020) Structure of the global plastic waste trade network and the impact of China's import Ban, Resources. Conserv Recycl 153:104591-104591. https:// doi.org/10.1016/j.resconrec.2019.104591

43. Giuffrida A, (2020). Italy told to stop using Malaysia as plastics dumping ground, The Guardian. https:// www.theguardian.com/world/2020/feb/10/italy-told-to-stop-using-malaysia-as-plastics-dumping-groundgreenpeace-landfill (accessed November 3, 2020) 
44. Nielsen TD, Holmberg K, Stripple J (2019) Need a bag? A review of public policies on plastic carrier bagswhere, how and to what effect? Waste Manag 87:428-440. https://doi.org/10.1016/j.wasman.2019.02.025

45. Jakovcevic A, Steg L, Mazzeo N, Caballero R, Franco P, Putrino N, Favara J (2014) Charges for plastic bags: motivational and behavioral effects. J Environ Psychol 40:372-380. https://doi.org/10.1016/j.jenvp. 2014.09.004

46. Wagner TP (2017) Reducing single-use plastic shopping bags in the USA. Waste Manag 70:3-12. https:// doi.org/10.1016/j.wasman.2017.09.003

47. Callicott JB (2002) The pragmatic power and promise of theoretical environmental ethics: forging a new discourse. Environ Values 11:3-25. https://doi.org/10.3197/096327102129340957

48. Littig B, Griessler E (2005) Social sustainability: a catchword between political pragmatism and social theory. IJSD. 8:65. https://doi.org/10.1504/IJSD.2005.007375

49. Milne MJ, Tregidga H, Walton S (2009) Words not actions! The ideological role of sustainable development reporting, Accounting. Aud \& Account J 22:1211-1257. https://doi.org/10.1108/09513570910999292

50. Smallman M (2020) 'Nothing to do with the science': how an elite sociotechnical imaginary cements policy resistance to public perspectives on science and technology through the machinery of government. Soc Stud Sci 50:589-608. https://doi.org/10.1177/0306312719879768

51. Nobre AL, Duarte R, Jacquinet MM, (2017) Heidegger, technology and sustainability: between intentionality, accountability and empowerment, 19th International Conf Enterprise Inform Syst. 186-190. doi: https://doi.org/10.5220/0006372401860190

52. Yadav G, Kumar A, Luthra S, Garza-Reyes JA, Kumar V, Batista L A framework to achieve sustainability in manufacturing organisations of developing economies using industry 4.0 technologies' enablers. Comput Ind 122(2020):103280. https://doi.org/10.1016/j.compind.2020.103280

53. Latta GS, Plantinga AJ, Sloggy MR (2016) The effects of internet use on global demand for paper products. J For 114:433-440. https://doi.org/10.5849/jof.15-096

54. Ali HMM, El-Gorashi TEH, Lawey AQ, Elmirghani JMH (2017) Future energy efficient data centers with disaggregated servers. J Lightwave Technol, JLT 35:5361-5380 https://www.osapublishing.org/jlt/abstract. cfm?uri=jlt-35-24-5361 (accessed October 29, 2020)

55. Satyro WC, Sacomano JB, Contador JC, Telles R (2018) Planned obsolescence or planned resource depletion? A sustainable approach. J Clean Prod 195:744-752. https://doi.org/10.1016/j.jclepro.2018.05. 222

56. Despeisse M, Baumers M, Brown P, Charnley F, Ford SJ, Garmulewicz A, Knowles S, Minshall THW, Mortara L, Reed-Tsochas FP, Rowley J (2017) Unlocking value for a circular economy through 3D printing: a research agenda. Technol Forecast Social Change 115:75-84. https://doi.org/10.1016/j. techfore.2016.09.021

57. Gall M, Wiener M, Chagas de Oliveira C, Lang RW, Hansen EG (2020) Building a circular plastics economy with informal waste pickers: recyclate quality, business model, and societal impacts, Resources. Conserv Recycl 156:104685. https://doi.org/10.1016/j.resconrec.2020.104685

58. Majumdar A, Shukla S, Singh AA, Arora S (2020) Circular fashion: properties of fabrics made from mechanically recycled poly-ethylene terephthalate (PET) bottles, Resources. Conserv Recycl 161:104915

59. Tisserant A, Pauliuk S, Merciai S, Schmidt J, Fry J, Wood R, Tukker A (2017) Solid waste and the circular economy: a global analysis of waste treatment and waste footprints. J Ind Ecol 21:628-640. https://doi.org/ 10.1111 jiec. 12562

60. Slorach PC, Jeswani HK, Cuéllar-Franca R, Azapagic A (2019) Environmental and economic implications of recovering resources from food waste in a circular economy. Sci Total Environ 693:133516

61. Iacovidou E, Velis CA, Purnell P, Zwirner O, Brown A, Hahladakis J, Millward-Hopkins J, Williams PT (2017) Metrics for optimising the multi-dimensional value of resources recovered from waste in a circular economy: a critical review. J Clean Prod 166:910-938

62. Imbert E, Ladu L, Tani A, Morone P (2019) The transition towards a bio-based economy: a comparative study based on social network analysis. J Environ Manag 230:255-265. https://doi.org/10.1016/j.jenvman. 2018.09.068

63. Felson M, Spaeth JL, (1978) Community structure and collaborative consumption: a routine activity approach, Am Behav Sci. 21. https://doi.org/10.1177/000276427802100411

64. Rowe PCM (2017) Beyond Uber and Airbnb: the social economy of collaborative consumption. Social Media + Society 3:2056305117706784. https://doi.org/10.1177/2056305117706784

65. Accenture, Using digital tech to spin the circular economy (2015). https://www.accenture.com/_acnmedia/ Accenture/Conversion-Assets/Outlook/Documents/2/Accenture-Outlook-Using-Digital-Tech-SpinCircular-Economy.pdf (accessed November 4, 2020)

66. Wosskow D, (2014) Unlocking the sharing economy: an independent review. https://www.gov.uk/ government/publications/unlocking-the-sharing-economy-independent-review (accessed November 4, 2020) 
67. Belk R (2014) You are what you can access: Sharing and collaborative consumption online. J Bus Res 67: 1595-1600. https://doi.org/10.1016/j.jbusres.2013.10.001

68. Wiedmann T, Lenzen M, Keyßer LT, Steinberger JK (2020) Scientists' warning on affluence. Nat Commun 11:3107. https://doi.org/10.1038/s41467-020-16941-y

69. Roy S, Cooper D, Mucci A, Sana B, Chen M, Castiglione J, Erhardt GD (2020) Why is traffic congestion getting worse? A decomposition of the contributors to growing congestion in San Francisco-Determining the Role of TNCs, Case Studies on Transport Policy. https://doi.org/10.1016/j.cstp.2020.09.008

70. Bucher E, Fieseler C, Lutz C (2016) What's mine is yours (for a nominal fee)-exploring the spectrum of utilitarian to altruistic motives for Internet-mediated sharing. Comput Hum Behav 62:316-326. https://doi. org/10.1016/j.chb.2016.04.002

71. Shrivastava A, Jain G, Kamble SS, Belhadi A (2021) Sustainability through online renting clothing: circular fashion fueled by instagram micro-celebrities. J Clean Prod 278:123772. https://doi.org/10.1016/j.jclepro. 2020.123772

72. Lenzen M, Sun Y-Y, Faturay F, Ting Y-P, Geschke A, Malik A (2018) The carbon footprint of global tourism. Nat Clim Chang 8:522-528. https://doi.org/10.1038/s41558-018-0141-x

73. Gössling S, Peeters P (2015) Assessing tourism's global environmental impact 1900-2050. J Sustain Tour 23:639-659. https://doi.org/10.1080/09669582.2015.1008500

74. Zervas G, Proserpio D, Byers JW (2017) The rise of the sharing economy: estimating the impact of Airbnb on the hotel industry. J Mark Res 54:687-705. https://doi.org/10.1509/jmr.15.0204

75. Mhlanga O (2020) The innovation-employment nexus: an analysis of the impact of Airbnb on hotel employment, Journal of Hospitality and Tourism Technology. ahead-of-print. https://doi.org/10.1108/ JHTT-09-2019-0111

76. OECD, (2019) Business models for the circular economy, Business Models for the Circular Economy. doi: https://doi.org/10.1787/g2g9dd62-en

77. Spring M, Araujo L (2017) Product biographies in servitization and the circular economy. Ind Mark Manag 60:126-137. https://doi.org/10.1016/j.indmarman.2016.07.001

78. Gutowski TG (2018) A critique of life cycle assessment; where are the people? Procedia CIRP 69:11-15. https://doi.org/10.1016/j.procir.2018.01.002

79. Alcayaga A, Wiener M, Hansen EG (2019) Towards a framework of smart-circular systems: an integrative literature review. J Clean Prod 221:622-634. https://doi.org/10.1016/j.jclepro.2019.02.085

80. Ashima S, Julia V, Brandt K, Yeoman R, (2017) Cities in the circular economy: the role of digital technology. https://www.ellenmacarthurfoundation.org/assets/downloads/Cities-in-the-Circular-EconomyThe-Role-of-Digital-Tech.pdf (accessed November 4, 2020)

81. Wong JKW, Zhou J (2015) Enhancing environmental sustainability over building life cycles through green BIM: a review. Autom Constr 57:156-165

82. BAMB - Building As Material Banks, BAMB. (2016). https://www.bamb2020.eu (accessed November 4, 2020)

83. Hart J, Adams K, Giesekam J, Tingley DD, Pomponi F (2019) Barriers and drivers in a circular economy: the case of the built environment. Procedia CIRP 80:619-624. https://doi.org/10.1016/j.procir.2018.12.015

84. M. Heinrich, W. Lang, Materials passports-best practice, 2019

85. Eberhardt LCM, Birkved M, Birgisdottir H (2020) Building design and construction strategies for a circular economy. Archit Eng Design Manag 0:1-21. https://doi.org/10.1080/17452007.2020.1781588

86. Shi L, Xiang X, Zhu W, Gao L (2018) Standardization of the evaluation index system for low-carbon cities in China: a case study of Xiamen. Sustainability. 10:3751. https://doi.org/10.3390/su10103751

87. Zink T, Geyer R (2017) Circular economy rebound. J Ind Ecol 21:593-602. https://doi.org/10.1111/jiec. 12545

88. Miller J (1974) Why the world is on the back of a turtle. Man. 9:306-308

89. Buchmann-Duck J, Beazley KF (2020) An urgent call for circular economy advocates to acknowledge its limitations in conserving biodiversity. Sci Total Environ 727:138602. https://doi.org/10.1016/j.scitotenv. 2020.138602

90. Gabbatiss J,(2020) In-depth Q\&A: How will tree planting help the UK meet its climate goals?, Carbon Brief. https://www.carbonbrief.org/in-depth-qa-how-will-tree-planting-help-the-uk-meet-its-climate-goals (accessed October 29, 2020)

91. Bendor R, Maggs D, Peake R, Robinson J, Williams S, (2017) The imaginary worlds of sustainability: observations from an interactive art installation, Ecology and Society. 22. https://www.jstor.org/stable/ 26270091 (accessed October 29, 2020)

92. Cullen JM, (2017) Circular economy: theoretical benchmark or perpetual motion machine?, Journal of Industrial Ecology. doi:https://doi.org/10.1111/jiec.12599

93. Le Quéré C, Jackson RB, Jones MW, Smith AJP, Abernethy S, Andrew RM, De-Gol AJ, Willis DR, Shan Y, Canadell JG, Friedlingstein P, Creutzig F, Peters GP (2020) Temporary reduction in daily global CO 2 
emissions during the COVID-19 forced confinement. Nat Clim Chang 10:647-653. https://doi.org/10.1038/ s41558-020-0797-x

94. Lenzen M, Li M, Malik A, Pomponi F, Sun Y-Y, Wiedmann T, Faturay F, Fry J, Gallego B, Geschke A, Gómez-Paredes J, Kanemoto K, Kenway S, Nansai K, Prokopenko M, Wakiyama T, Wang Y, Yousefzadeh M (2020) Global socio-economic losses and environmental gains from the Coronavirus pandemic. PLoS One 15:e0235654. https://doi.org/10.1371/journal.pone.0235654

95. Vollset SE, Goren E, Yuan C-W, Cao J, Smith AE, Hsiao T, Bisignano C, Azhar GS, Castro E, Chalek J, Dolgert AJ, Frank T, Fukutaki K, Hay SI, Lozano R, Mokdad AH, Nandakumar V, Pierce M, Pletcher M, Robalik T, Steuben KM, Wunrow HY, Zlavog BS, Murray CJL (2020) Fertility, mortality, migration, and population scenarios for 195 countries and territories from 2017 to 2100 : a forecasting analysis for the Global Burden of Disease Study. Lancet 396:1285-1306. https://doi.org/10.1016/S0140-6736(20)30677-2

96. Yoshida S, Hiraga K, Takehana T, Taniguchi I, Yamaji H, Maeda Y, Toyohara K, Miyamoto K, Kimura Y, Oda K (2016) A bacterium that degrades and assimilates poly(ethylene terephthalate). Science 351:1196 LP-1191199. https://doi.org/10.1126/science.aad6359

97. Allwood JM (2018) Unrealistic techno-optimism is holding back progress on resource efficiency. Nat Mater 17:1050-1051. https://doi.org/10.1038/s41563-018-0229-8 